\title{
The Role of Opinion Leaders in Diseminating Climate Change Policy
}

\author{
Agusniar Rizka Luthfia ${ }^{1}$ and Eka Nada Shofa Alkhajar ${ }^{2}$ \\ ${ }^{1,2}$ Faculty of Social and Political Sciences, Universitas Sebelas Maret, Indonesia \\ 1agusniar@staff.uns.ac.id, ${ }^{2}$ ekanadashofa@staff.uns.ac.id
}

\begin{abstract}
Opinion leaders have important roles to boost the successful of the government policies and programs implementation. The climate village program is a form of national climate change policy to reduce climate change impacts. The program will not run smoothly without roles from various parties, especially the opinion leaders. The research aimed to reveal the roles of opinion leaders in encouraging the implementation of national climate change policy at the grassroots level. This research was a qualitative descriptive study conducted in Pendulan Hamlet, Sleman. The results of this study found that the successful implementation of the national climate change policy in the form of a climate village program at the hamlet cannot be separated from the role of its opinion leaders. The research found that opinion leaders have played strategic and crucial roles in bringing the successful of the climate village program implementation. There were at least three important roles played by opinion leaders on the success of the program. The roles they played that support the success of the program were motivator, initiator and communicator.
\end{abstract}

Keywords: opinion leaders, climate village program, policy implementation

\section{INTRODUCTION}

Climate change is a global problem that required well management. It is a real threat throughout world, including Indonesia. Indonesian national law No. 32 of 2009 on Environment Protection and Management has stated that Indonesia is on a vulnerable position to the climate change impacts. Indonesian government has made a national policy to cope with the impact of climate change through climate village program starting from grassroots level. However, the successful of a program, including this program, is highly determined by factors existing in the field. One of which is the existence of opinion leaders [1]. They are an important part of villagers or hamlets people contributing to diseminate new knowledge within the community [2][3].

Theoretically, they are a group of people with ability of persuading many people, particularly in rural areas because they have many advantages other common villagers do not have [4]. Unfortunately, many parties do not understand the important role of these actors. The actors in the field are either formal or informal in nature, but contribute considerably to a policy implementation. As a public policy taken by the government in the attempt to reduce climate change impacts, the government of course expects that the policy in the form of climate village program can be implemented well and successfully throughout Indonesian areas. Therefore, a measure is required to translate the policy into action [5][6]. 
Previous studies have been conducted on the role of opinion leaders by, among others, La Jaali et al. [7], Istiari [8], Sudahri and Arsali [9]. The findings of previous studies showed that opinion leaders play an important role in the societal life. Nevertheless, the scope of opinion leaders' roles are still territorially bordered. There is not yet a study has been conducted on the role of opinion leaders in hamlet particularly in the implementation of national policy enacted throughout Indonesia. The policy can be implemented well on the grassroots level such as in Sleman Regency. The regency is one of regencies successfully implementing climate village program. It can be seen from many hamlets winning award from the Ministry Ministry of Environment and Foresty related to the program. One of them is Pendulan Hamlet that won the award in 2016.

A research has indicated the important roles played by opinion leaders behind a successful implementation of national climate change policy in the hamlet [10]. Nevertheless, these roles have not been explored in detailed and thereby requiring a more in-depth research to identify and to find out the roles played by opinion leaders. It particularly relates to the reality in which members of society are encouraged and participate actively in making the implementation of the national climate change policy successful in the form of climate village program. The people take two important ways i.e. adaptation and mitigation actions until their hamlet acquiring national recognition.

As a case study, the research on Pendulan Hamlet was conducted to find out the roles of opinion leaders successfully encouraging the implementation of national climate change policy at the grassroots level. It is expected to increase knowledge, scholarship development, and empirical finding on the important role of opinion leaders in policy implementation area. In addition, the empirical finding of the research can also be used as an input for the stakeholders and related institutions to maximize the roles of hamlet opinion leaders in the attempt of implementing policies.

\section{METHOD}

The study was a descriptive qualitative research. It carried out in Pendulan Hamlet as a case study. The three methods conducted to gather data were interviews, field observation and documentation. The snowball technique was used to identify the competent informants known as opinion leaders in the hamlet. The research performed data source triangulation for data validation. An interactive model analysis was used to analyze data. It involved components such as data collection, data reduction, data display, and conclusion drawing and verifying. The result of data analysis was reported descriptively [11][12][13][14].

\section{RESULT AND DISCUSSION}

Pendulan Hamlet is located at Sumberagung Village, Moyudan Subdistrict, Sleman Regency. The hamlet is one of 1,212 hamlets in the region and has a six hectares-area wide. Total number of populations living in this hamlet is 120 family heads or 545 people. Making farm is done by majority population for their livehood. This hamlet has abundant water source on both rainy and dry seasons, particularly in the presence of irrigation channel in the right and left of settlement street. A variety of environment-based actions have been taken by the people including independent waste management at household level, yard optimization, and rainwater harvesting to encourage a sustainable environment management. In addition, Pendulan Hamlet has a good topographic condition. Although it belongs to lowland, it has never encountered landslide, drought, and flood. Nevertheless, the potential vulnerability is 
rainfall pattern alteration as one of the impacts of climate change. It is a main threat as it can affect plantation activity. Moreover, majority of its population are farmers. In addition, the risk of rain pattern change is an effect of climate change that can threat farming activity constituting the people's livelihood [10][14][15].

Related to climate village program, the hamlet has performed two main actions i.e. adaptation and mitigation in combating climate change. The yard optimization is one of adaptation actions carried out by the people. They utilize their yard to plant traditional medicinal plants, fruit and vegetable plants as well as utilize it as fish ponds. These actions are closely related to strengthen health resilience, food resilience, and water resilience. The traditional medicinal plants used to meet the household need. The fruit and vegetables plants to enhance household nutrition and food security. Meanwhile, the fish ponds used for water reservoir or water storage to collect rainwater [10]. In addition, they also make water reservoir holes and irrigation channel as attempts o prevent drought. The irigation channel is created by damming a river to then drain the water into the irigation channel so that the water supply is abundant. It also can be used for watering people's plants.

Meanwhile, mitigation actions carried out by the people i.e. waste management, save water and electricity. Waste management i.e. organic fetilizer production, plastic crafts, patchworks and the 3Rs movement (reuse, reduce, and recycle). Since 2014, a waste bank named "Pendulan Berseri" has been founded and it operated until today. Waste management is very important to carried out. As is known, unmanaged waste piles are one of the sources of greenhause gas emissions. Meanwhile, saving water and electricity actions are taken by using wood-saving stoves, glass tiles for the daytime lighting and shower heads for the bathroom. In addition, as a part of mitigation actions, the people also plant green vegetation and care of the forest to produce oxygen and reduce greenhouse gas emissions.

These actions-based environment have been intensively carried out since 2012. After passing various assesments the hamlet won a national award as a climate village from the Ministry of Environment and Foresty in 2016. Nevertheless, initially Pendulan Hamlet was not included as a famous and highlighted hamlet. However, the condition changed when it received the national award. Since then, the hamlet has been increasingly highlighted and used as an example of other government programs. The successful implementation of the national climate change policy in the form of a climate village program at the hamlet cannot be separated from the role of its opinion leaders. The research found that there were at least three important roles played by opinion leaders on the success of the program.

First, the role as communicator. After learning the government program, opinion leaders disseminate the information to the people. They always try to provide an understanding of the importance of the climate village program and explain in detail about it. They also inform, provide and diseminate many climate change issue and how to cope with it. At this point, they have carried out development communication practices [16][17]. One thing is for certain, the opinion leaders have a good communication skill to persuade the people to carry out adaptation and mitigation actions in their hamlet.

Second, the role as initiator. The opinion leaders in Pendulan Hamlet immediately moved to take action on adaptation and mitigation starting from themselves. They tried to give examples in advance to the people. They plant vegetables, fruits and traditional medicinal plants in their yards. They argue that the best way to get citizens to implement the program is to provide examples at first.

Third, the role as motivator. The opinion leaders always motivate the people to take action on adaptation and mitigation, including providing them the necessary equipments such as plant seeds, polybags and pots. They also visit each of the households to ensure that all of 
them take actions related to the climate village program. They believe that door-to-door strategy to motivate and communicate is one of the best way to approach the people. It can be seen that opinion leaders maximize the nature of intimate relationships to benefit the program [18]. Until now the opinion leaders continue to carry out these roles and thus continue to remind the importance of protecting the environment in the framework of combating climate change. They realized the program is one of the ways to create a climate-friendly planet for the grassroots level [19][20]. Based on these findings it can be said that the opinion leaders are the spearhead of government policies.

\section{CONCLUSION}

At rural level, opinion leaders evidently play an important role in disseminating a public policy. The successful dissemination even encourages the successful implementation of public policy directly, in this context, the climate change policy in the form of climate village program. This study conducted in Pendulan Hamlet has affirmed the importance of the opinion leaders' roles. Their roles include: being initiator, communicator, and motivator. Those roles can be played well because they exert considerable effect on hamlet people. Therefore, eventually hamlet people are willing to implement climate village program gradually and voluntarily. They take adaptation and mitigation actions together to reduce the impacts of climate change in their village. Viewed from policy cycle perspective, particularly policy implementation, it can be seen that tight coordination, cooperation, and collaboration between governmental elements and opinion leaders at grassroots level is very desirable to make the implementation of climate change policy running smoothly and successfully.

\section{ACKNOWLEDGEMENT}

The authors would like to thank the Directorate General of Resources for Science Technology and Higher Education, Ministry of Education and Culture of the Republic of Indonesia for the financial support of this research.

\section{REFERENCES}

[1]. E. Rogers. Diffusion of Innovations. New York: The Free Press, 1995.

[2]. E. A. Chatman. "Opinion Leadership, Poverty, and Information Sharing." $R Q$, Vol. 26, No. 3, pp. 341-353, 1987.

[3]. G. Feder and S. Savastano. "The Role of Opinion Leaders in the Diffusion of New Knowledge: The Case of Integrated Pest Management." World Development, Vol. 34, No. 7, pp. 1287-1300, 2006.

[4]. G. Weimann. The Influentials. Albany: State University of New York Press, 1994.

[5]. T. R. Dye. Understanding Public Policy. New Jersey: Prentice-Hall, 1981.

[6]. S. M. Barrett. "Implementation Studies: Time for a Revival? Personal Reflections on 20 Years of Implementation Studies.” Public Administration, Vol. 82, No. 2, pp. 249-262, 2004.

[7]. L. Jaali, H. Cangara and Hasrullah. "Peran Pemuka Pendapat (Opinion Leader) Dalam Memelihara Kedamaian di Tengah Konflik Horizontal Di Desa Wayame Ambon”. KAREBA, Vol. 2, No. 3, pp. 251-258, 2013.

[8]. T. Istiari. "Peran Pemuka Pendapat Dalam Meningkatkan Partisipasi Pilkades di Desa Prangkat Selatan Tahun 2013." eJournal Ilmu Komunikasi, Vol. 1, No. 4, pp. 106-119, 2013.

[9]. Sudahri and R. Arsali. "Peran Pemuka Pendapat Dalam Program Bedah Rumah di Desa Sukorambi Jember.” MEDIAKOM, Vol. 1, No, 1, pp. 68-96, 2017. 
[10]. E. N. S. Alkhajar and A. R. Luthfia. "The yard optimization as an adaptation strategy in combating climate change: a case study in Pendulan Hamlet, Sleman, Indonesia." IOP Conference Series: Earth and Environmental Science, Vol. 200, No. 1, pp. 012032, 2018.

[11]. R. K. Yin. Case Study Research: Design and Methods. 2nd ed. Thousand Oaks: Sage Publications, 1994.

[12]. J. R. Ledford and D. L. Gast. Single Case Research Methodology: Applications in Special Education and Behavioral Sciences. New York: Routledge, 2018.

[13]. M. B. Miles and A. M. Huberman. Qualitative Data Analysis.Thousand Oak, CA: Sage Publications, 1994.

[14]. K. F. Punch. Introduction to Social Research: Quantitative and Qualitative Approaches. London: Sage Publications, 1999.

[15]. BLH Kabupaten Sleman. Climate Village Program. Sleman: Badan Lingkungan Hidup Kabupaten Sleman, 2015.

[16]. BPS DIY. Daerah Istimewa Yogyakarta Province in Figures 2017. Yogyakarta: BPS Provinsi Daerah Istimewa Yogyakarta, 2017.

[17]. E. N. S. Alkhajar. "Media Tradisional dan Komunikasi Pembangunan." Journal of Rural and Development, Vol. 2, No. 2, pp. 133-138, 2011.

[18]. E. N. S. Alkhajar. Media, Masyarakat dan Realitas Sosial. Surakarta: Sebelas Maret University Press, 2014.

[19]. A. R. Luthfia. "Menilik Urgensi Desa di Era Otonomi Daerah." Journal of Rural and Development, Vol. 4, No. 2, pp. 135-143, 2013.

[20]. A. R. Luthfia and E. N. S. Alkhajar. "Strengthening public awareness on climate change: lesson learned from a youth social movement in Yogyakarta, Indonesia." IOP Conference Series: Earth and Environmental Science, Vol. 200, No. 1, pp. 012033, 2018. 